Dinamika Sosial Budaya, Vol 21, No. 2, Desember 2019, pp 98-109

p-ISSN: 1410-9859\& e-ISSN: 2580-8524

http://journals.usm.ac.id/index.php/jdsb

\title{
Hukou and Citizenship Rights in China: A Case Study on Migrant Labour
}

\author{
Sumesh Manganelly \\ Department of Politics, East China Normal University \\ sumeshmn08@gmail.com
}

\begin{abstract}
This article is going to discuss hukou in detail and how it juxtaposes with citizenship rights of migrants in China. The first part of this article deals with China's hukou policies and its implications on Chinese society and going to discuss how migrants are trying to fit city life even within this tight and strict hukou system. The second section talks about the denial of the complete citizenship to the floating population in their country, and how they are treated as secondary citizens by urban people. Also, article tries to bring the basic concept of citizenship in the light of the state policies of denial of their rights and discriminating its rural population even though they have been the fuel of Chinese rapid economic and infrastructural growth and made China as world's factory. The third and final part examines the provisions of hukou and juxtaposes them with the notion of citizenship to show how they contradict each other in contemporary China in the era of domestic migration. So, it is a bit difficult situation to clarify those Chinese concepts of legitimising their views with the modern concept of citizenship. Still, it is an attempt to elaborate and conceptualise life and rights of migrants in Chinese cities.
\end{abstract}

Keywords: China, Migrants, hukou, Citizenship rights

\section{Introduction}

China is strictly following the Household Registration System (Húkǒu, 户口 )$^{* *}$ to control and prohibit the internal migration since state introduced the hukou system under the red flag of the People's Republic of China (PRC). The hukou which was implemented in 1958 has a significant role in determining the social benefits that the people of the country are entitled to. It has been the part of Chinese life for the last six decades, and it continues to exist,and its presence becomes more complex in the day to day people's life. The hukou has divided the entire population in the country geographically and socially into two, i.e. urban and rural. The main objective behind the hukou was to prohibit the domestic migration especially from villages to cities. With the help of different institutions like village collectives (gōng shè, 公社) and urban work units (dānwèi, 单位), the state executed such policies in a very effective manner, and no one can escape from its octopus hands till reform era started. The state's welfare, privileges, and all other services were decided only by existing hukou. If one was born with urban or rural hukou, then he or she has to die with that same hukou status. There is no change of their registration. But still, it is one of the main socio-economic institutions in China. An approximate number of migrants are more than 275 million distributed in different cities (Becker, 2014) which are noted as the largest peaceful migration ever in human history. From the traditional agricultural sector, they started exploring other life and employment opportunities in the cities. Some studies have begun to look at migration concerning social institutions such as the hukou system (e.g. Yang, Y. 1996; Chan, 1996; Wang and Zuo, 1997; Wang, 1997; Li and Siu, 1997; Solinger, 1999) and as well as the impact of migration on the economy and society and related policy issues (e.g. Solinger, 1995, 1999; Nolan, 1993; Wan, 1995; Chan, 1998). For rural to urban migration and issues with migrants in cities one has to read hukou along with their citizenship rights.

Is China abolishing its hukou policies? How hukou denies complete citizenship status to floating population? How does hukou itself discriminate migrants in the cities? Here in this article, author discusses the relationship between hukou and citizenship rights in the context of huge migrant population. Author argues that any 
Dinamika Sosial Budaya, Vol 21, No. 2, Desember 2019, pp 98-109

p-ISSN: 1410-9859\& e-ISSN: 2580-8524

http://journals.usm.ac.id/index.php/jdsb

serious and meaningful research on migration in China must start by making reference to the hukou system because this affects the migration in different ways. And, author also argue that the hukou system remained a relatively powerful institution in structuring migration in the late 1980s and that the same institution discriminates and treat its rural people like secondary citizens.

There have been mainly two types of rural to urban migration which are legal and illegal migration. The person who migrates to the city by registering with both local authorities (rural as well as destination place) is known as a legal migrant. This system has started in the mid of 1980 s onwards. But since the 80 s, there was another type of population flows penetrated cities in which they never registered in any of the two authorities. But they kept on moving from one place to other as wandering beggars. Already people from the countryside never had any good privileges as urban people do, so moving to a city without any known person in the city is a bit difficult to survive for an ordinary village man. Here comes the universal citizenship or ideal citizenship of common people in the same country. China's cases always differ from any other country in the world. In this situation and reign of so-called hukou system, the state used to divide and treat its people with two different ways.

\section{Hukou System and Floating Population}

The issues of floating population and hukou and their relationship are becoming much more relevant in the history of contemporary China especially since its reform policies which took place in the late 1970s. Till the 1970s from the foundation of PRC the Chinese society was not market-based and China was in the path of construction of socialism under their then Chairman Mao Zedong. China had alienated itself from the world, and its society was closed. The rate of urbanisation was very slow in nature, and its population was limited and regulated the migration from rural to urban by imposing strict hukou policies, and only state-led migration was there. A self-initiated relocation to a city from a village was only a dream for an ordinary peasant. Such a change is granted only when certain limited conditions are met, especially when the move serves the state's interests defined in various policies, such as state recruitment and transfers of personnel. Even today, peasants can travel to many places, but getting a registration to be a full-status urban resident in a medium-sized or large city is still largely beyond their reach (Chan, 2001:128129).

There are two categories of migration since reform which is hukou migration (those have local hukou residency rights) and nonhukou migration (those without hukou residency rights). In China, officially the hukou migration is only considered as migration (qiānyi, 迁移), anything other than this is known as population movement or floating (liúdòngrénkǒu, 流动人口 ) (Chan, 2001). The floaters are not supposed to stay legally in any city permanently (temporary migrants). The significant amount of migration which China has witnessed since reform is of the non-hukou migration variety.

Table 1 Hukou and non-hukou rural-urban migrants

\begin{tabular}{lll}
\hline \multicolumn{1}{c}{ Characteristics } & \multicolumn{1}{c}{ Hukou migrants } & \multicolumn{1}{c}{ Non-hukou migrants } \\
\hline $\begin{array}{l}\text { Household registration type } \\
\text { and status }\end{array}$ & $\begin{array}{l}\text { Non-agricultural and } \\
\text { local }\end{array}$ & Agricultural and non-local \\
$\begin{array}{l}\text { Entitlements to state-supplied } \\
\text { social benefits and } \\
\text { opportunities }\end{array}$ & Full & $\begin{array}{l}\text { From nil to temporary } \\
\text { entitlements }\end{array}$ \\
$\begin{array}{l}\text { Legal urban residency status } \\
\text { Full status }\end{array}$ & Fullegal or temporary \\
\hline
\end{tabular}


Dinamika Sosial Budaya, Vol 21, No. 2, Desember 2019, pp 98-109

p-ISSN: 1410-9859\& e-ISSN: 2580-8524

http://journals.usm.ac.id/index.php/jdsb

\begin{tabular}{|c|c|c|}
\hline Characteristics & Hukou migrants & Non-hukou migrants \\
\hline Socioeconomic sector & Mostly inthestate sector & $\begin{array}{l}\text { Mostly in the non-state sector; } \\
\text { also as temporary workers in } \\
\text { state sector }\end{array}$ \\
\hline $\begin{array}{l}\text { Mechanism of effecting } \\
\text { migration }\end{array}$ & $\begin{array}{l}\text { Determined by } \\
\text { bureaucratic decisions } \\
\text { within plan limits }\end{array}$ & $\begin{array}{l}\text { Spontaneous', based on } \\
\text { personal contacts and market } \\
\text { information }\end{array}$ \\
\hline Stability of moves & Permanent & Seasonal or semi-permanent \\
\hline $\begin{array}{l}\text { Labour characteristics of } \\
\text { principal migrants Skill level }\end{array}$ & $\begin{array}{l}\text { Skilled and low-skilled } \\
\text { workers }\end{array}$ & $\begin{array}{l}\text { Mostly unskilled or low- } \\
\text { skilled labour }\end{array}$ \\
\hline Employment type & Mostly permanent jobs & $\begin{array}{l}\text { Temporary or semi-permanent } \\
\text { jobs in non-state enterprises; } \\
\text { or self-employment }\end{array}$ \\
\hline Housing & $\begin{array}{l}\text { Same as other urban } \\
\text { residents }\end{array}$ & Low-cost shelters or homeless \\
\hline
\end{tabular}

Source: Chan, Liu and Yang (1999:427)

Table 1 shows the basic characteristics of hukou and non-hukou migrants. This table clearly indicates that there is a vast disparity between rural and urban people. Migrants (nonhukou) treated as an outsider in the urban spaces, and the state has thrown them in the periphery of the welfare and socio-economic schemes. Even a foreign person can get good hospitality, but an individual who born and brought in China has to face various discrimination. The transients are outside of state's benefits but in the same context they are the people who help to accelerate the urbanisation process, infrastructural development and are a major part of country's manufacturing boom. Urban dwellers are entitled to subsidised grain rations and other goods, work allocation by labour bureau, subvented housing, social insurance, health care, and cultural and urban amenities provided at state expense. As such, urban household status has been closely linked to the state's rationing system of vital goods and services (Wong, 1994:336). Urbanites are politically and economically protected class since Mao's era. But in the post-reform period, it got devolution in a certain way which led to the creation of new urban class of laid off labour or new urban poor in contemporary China. With the opening of markets since the late 1970s, the segregation began to break down, and a mass number of villagers made their way to the city, but still one way or other their segregation did not come to an end, they have been sidelined by the urbanites and the state.

\subsection{Migrants and Urban Villages}

The role played by the 'urban villages' (chéngzhōngcūn, 城中村) in the growth of China as the world's manufacturer has been crucial because of the comparatively affordable shelters it provided for the migrant population. These villages act as the migrants' entry point into the city. The large-scale urban expansion that engulfs the farmlands around leads to the formation of urban communities. This urban village phenomenon is very common in Chinese cities. We can understand it as a phenomenon resulting from the large-scale urban expansion that envelopes farmlands and therefore resulting in an urban village. In the urban community, land ownership is a kind of collective ownership; therefore, the state is unable to make significant adjustments in the process of largescale development. Such villages have gone 
through some constant changes and upgrades which could be due to market behaviour or could also be the government's beautifying behaviour. The quality of urban villages varies. There are two types of villages: villages in the middle of the city and villages at the periphery. The migrant enclaves are the by-products of rapid urbanisation, and these villages are becoming the hub of migrants.

The character of migrant enclaves varies from city to city and even within the villages. The rural migrants work as a channel to recruit further migrants from their villages. So they try to keep their cultural identity and make an ambience to feel like they live with their community people as well as in their village. Despite this, they also take efforts to become part of urban culture. But the real challenge is that Chinese government wants to restructure and beautify the city, so one day they have to move from those enclaves. The place already part of rapid urbanisation process and the area has much more population density than that accommodative which leads to many other social issues like increasing crime rate, hygiene problem, pollution and so on. However, migrant enclaves are under the pressure of bulldozing any day on upcoming days.

\subsection{Migrants' Residence Condition in Cities}

Rural migrants can or may live in the city for years with the help of temporary household registration, but they cannot enjoy the same rights or privilege provided by the state as those having the permanent urban hukou. The term "temporary' is not very easy to define here in this context due to various limitations on the duration of stay by the migrants. The temporary urban hukou policy specifies neither the maximum period of residence nor the possibility of conversion to permanent hukou. There are few ways for rural migrants to change their 'temporary' residence into the permanent residence status (Zhang, 2011:254). So the permanent residence with the blessing of the state is not possible in a short period. Because the Chinese cities are already filled with much more than their capacity, that's why issuing permanent hukou means straining resources of the state. Housing choice is another issue faced by migrants, and it is widely constrained by their low income and limited urban citizenship. Due to their employment in low paid and uncertain work, they cannot afford decent housing in cities. There is no low-income affordable housing sponsored by local city governments for urban low-income groups, especially migrants. So they have to opt for the least expensive private housing, which is generally of the overcrowded and poor condition.

Table 2 Housing types of temporary population in cities (\%)

\begin{tabular}{lcccccc}
\hline Year & $\begin{array}{c}\text { Dormitory } \\
\text { provided by } \\
\text { employers }\end{array}$ & $\begin{array}{c}\text { Rental } \\
\text { house }\end{array}$ & $\begin{array}{c}\text { Construction } \\
\text { site }\end{array}$ & $\begin{array}{c}\text { Hotel or } \\
\text { guest } \\
\text { house }\end{array}$ & $\begin{array}{c}\text { Relatives } \\
\text { or friends } \\
\text { house }\end{array}$ & Others \\
\hline 1997 & 30.36 & 27.75 & 17.16 & 9.44 & 11.24 & 4.05 \\
1998 & 29.30 & 28.05 & 15.80 & 11.91 & 11.00 & 3.93 \\
1999 & 29.56 & 31.06 & 16.13 & 9.21 & 10.22 & 3.82 \\
2000 & 29.90 & 32.37 & 15.70 & 8.48 & 9.36 & 4.20 \\
2001 & 31.64 & 35.52 & 14.27 & 5.91 & 8.72 & 3.94 \\
2002 & 30.28 & 38.36 & 13.34 & 6.26 & 8.08 & 3.67 \\
2003 & 30.11 & 41.05 & 12.59 & 4.33 & 7.39 & 4.53 \\
2004 & 27.89 & 44.07 & 11.72 & 4.34 & 7.36 & 4.62 \\
2005 & 26.96 & 45.66 & 10.44 & 5.23 & 7.32 & 4.39 \\
2006 & 25.15 & 47.85 & 10.10 & 5.42 & 7.19 & 4.29 \\
2007 & 24.82 & 50.14 & 8.43 & 4.52 & 7.04 & 5.03 \\
\hline
\end{tabular}

Source: Ministry of Public Security (various years), Wong \& Rigg (eds.), 2011:255. 
Dinamika Sosial Budaya, Vol 21, No. 2, Desember 2019, pp 98-109

p-ISSN: 1410-9859\& e-ISSN: 2580-8524

http://journals.usm.ac.id/index.php/jdsb

Table 2 shows the temporary workers, who are primarily composed of migrants from the rural areas and the housing types in cities. The data illustrates that the percentage of dormitory provided by employers decreasing year by year and they have to go for rental housing, which boosts the private rental housing market. Along with this, we can see an increasing percentage of the rental house from 1997 to 2007. Approximately more than half of the temporary workers have to rely on private rental housing accommodation in the urban spaces. The percentage of migrants who stay in hotel or guest house's percentage has also significantly reduced over the years due to high expenses of rent and living expenditures, and they must have to look for cheap housing options in the city. Another important factor one has to focus that the role of employers to provide accommodation to their employees is notably declining. This data shows that the employers do not want to give any benefits to employees apart from basic salary. Only one-fourth of the employers provide dormitory only to those working in construction and manufacturing sectors.

Regarding the residential concentration of rural migrants, many studies have shown that they are often concentrated in particular migrant zones where social and environmental problems are severe. These migrant settlements stand in sharp contrast to wealthy districts regarding the living landscape and exemplify a significant dimension of spatial marginalisation in transitional urban China (Wu et al., 2014).

\subsection{Rural Labour Transfer to Urban Work Units Without Hukou}

With the beginning of urban economic reforms (the early 1990s), in which created a huge labour vacuum in both state enterprises and newly created non-state enterprises. The establishment of Special Economic Zones (SEZ) in coastal provinces invited surplus rural labour. So the rural people considered this as their second best option (Guang and Zheng, 2005) apart from working in village enterprise or farm land. The rural population fled to cities for better opportunities. These temporary workers worked in both state and non-state workplaces without any other employment benefits other than salary. But for them, it was a new life experience and enjoyed their situation because their great dream of working in cities had come true. They have been part of most of the working sectors in city, mostly as unskilled labour. On the contrary the present generation, we could say the second generation migrants have hardly any idea about farming and other agricultural related works, but they got a better education than the former generation.

Table 3 Rural Labour Transfer, 1995-2005 (in millions)

\begin{tabular}{cccccc}
\hline Year & \multicolumn{3}{c}{ New recruitment of urban work- } & \multicolumn{2}{c}{ Rural labour working in urban } \\
units \\
\cline { 2 - 6 } work-units
\end{tabular}

Source: Zhang, 2011 
Dinamika Sosial Budaya, Vol 21, No. 2, Desember 2019, pp 98-109

p-ISSN: 1410-9859\& e-ISSN: 2580-8524

http://journals.usm.ac.id/index.php/jdsb

The table 3 presents the rural population transfer to the urban work units, but it does not show other classified groups include college graduates, demobilised servicemen and so on. The rate of migrants' intake in the urban work units is increasing in the consecutive years, at the same time data also illustrates the declining rate of urbanites' recruitment. The central issue in which urbanites blame the migrants is that they are the reason for unemployment in the city. But migrants mostly do the 3D (dirty, difficult and dangerous) works which are less privileged and which urbanites consider beneath them to do. But for some extent the induction of rural population into the city captured much of the employment space from urbanites.

\section{Rural Migrants and Citizenship Rights}

The basic idea of citizenship has always been associated with the nation-state. Bryan $S$ Turner says that citizenship has two critical components, and it is possessed by those who have authoritatively been determined: a) to belong to the community and $b$ ) to have rights to share in the public distribution of its goods. In other definition, it is all about rights and privileges of individuals, who are legally living within specifically designated border which means in any country (Solinger, 1999). But here in the Chinese case, something is very different from these concepts. According to the concept of citizenship, everyone belongs to a particular nation and should be treated equally, in China people has divided into two by hukou and country people is spread over the cities. Still, there is an invisible division among the people. Those transients are not treated equally by urbanites and the state. They lack rights and privileges which provided to their counterpart citizens having urban hukou. Apart from showing this structural discrimination since the establishment of PRC, urbanites consider them as second class citizens. They are certainly not citizens there due to lack of urban hukou (primarily non-agricultural hukou). Because of this deprivation, it is clear that peasant migrants have official ineligibility for any medical, educational, housing, welfare or services of any sort in the cities. So migrants have to adjust and coexist with urbanites without any privilege or necessary right from the state.

\subsection{Social Exclusion of migrants in Cities}

The people from the countryside are excluded in many ways in China's transitional cities, mainly due to their ineligibility to access public goods and services. There is no chance to get permanent hukou status; so they have to face many challenges in their day to day life.

\subsubsection{Residence Right}

The residence rights of migrants are similar to foreign nationals living as 'guest workers'. They do have any right to buy property, to bring their spouses or children with them, or even any to residency (Chan, 1998). Solinger (1999) says that regulations forbade outsiders not just from building or buying houses (unless one was an Overseas Chinese), but even from occupying the land.

Table 4 Housing tenure for rural, urban, and migrant households, 2002 and 2007 (\% of households)

\begin{tabular}{ccccccc}
\hline & \multicolumn{3}{c}{2002} & & \multicolumn{2}{c}{2007} \\
\cline { 2 - 7 } & Rural & Urban & Migrant & Rural & Urban & Migrant \\
\hline Renters & 0.8 & 18.2 & 58.1 & n.a & 9.8 & 74.5 \\
Owners & 98.8 & 78.8 & 7.2 & n.a & 88.7 & 3.9 \\
Reform housing & & 60.7 & & & 54.9 & \\
commodity housing & & 7.4 & & & 27 & \\
inherited, self-built, & & 9.7 & & & 6.8 & \\
and other & & & & & & \\
Other/missing & 0.3 & 4 & 34.7 & n.a & 1.5 & 21.6 \\
\hline
\end{tabular}

Note: Shi and Sicular et al. (2013) 
Migrants have to meet the social discrimination by the local residents in the region in which they are employed. The urban housing policy has changed many times since the 1980s. Now people have property rights, but they can own property only in particular hukou places, which means, a person has an urban hukou cannot own property in the rural area and vice versa. However, with the help of this policy, urbanites entered into the real estate and housing markets. But migrants have to either rent a house or stay as paying guest with no prospect of holding any property in non-hukou regions. There are another group of villagers who have less fortune, jobless and could not afford a certain form of shelter, or lacked the money to rent a room or bed. During the nineties, their numbers had multiplied in the cities. They found a place for a stay in hidden back streets, under trucks and buses, in the parking lot, in tunnels, in the waiting areas of railway stations, and under bridges (Solinger, 1999).

Some report says that on shacks of just 300 square meters in Beijing holding more than 500 people or offering just one toilet for over 6000 people. The shelter to this marginal group needed to be made with the rudest of adaptations of scrap metal, cardboard, and wood. The population fled from the countryside is attributed as one of the main reasons for the boom in the urban real estate regime. It is very much visible that migrants stay in suburb areas, and particularly people from the same village or province remain in some particular locality (migrant village or peasant enclave). The sojourning peasants have almost no urban home ownership; housing surveys carried out in Beijing and Shanghai shows this fact, which finds that the ownership of housing is lower than one percentage among migrants (Wu, 2002).

Table 4 presents the varieties households of three distinct groups of population in two different years (2002 and 2007), in which the household ownership rate of transient peasants have significantly reduced from 2002 to 2007 from 7.2 percentages to 3.9 percentages which substantiate the migrants' incapability or ineligibility to own houses in the city. The percentage of renting household is dramatically increased from 58.1 percentages to 74.5 percentages which show almost all migrants have to depend on the private renting residence. We have to have a very clear understanding here that the state policies repeatedly shows discrimination and partiality one side to migrant labour and on the other side urbanites taking advantages of new urban housing policies as well as private property constructions and earning the pretty good amount of money from renting it to outsiders.

\subsubsection{Health Care System}

In a country like China, state funding for public health facilities, medication were planned based on the official urban population per city, so local bureaucrats are troubled to arrange such facilities of health care for newcomers from the villages. Even as responsible authorities decried the implications for the settled population of ignoring the epidemics and contagious diseases carried in by the migrants, they were too starved of resources to do anything much about it (Solinger, 1999). In this case, floaters have to look for some other health care options. But there were medical centres established and maintained by migrants those who were living in different migrant enclaves (example migrant enclaves like Zhejiang village in Beijing). Here Zhejiang people in Beijing had created their clinics and hospitals by the mid of the 1990s, where treatment provided by fellow Zhejiangese, who are holding medical licenses from home. However, medical consultation and treatment are very expensive in cities which are unbearable to migrant workers, but they have to adjust with and live accordingly. Due to high population density and hygiene issues in the migrants' living space, there are always chances for the epidemics to spread, which creates their life more vulnerable.

\subsubsection{Educational Rights}

Like any other facilities, the transients are not entitled to the state basic education policy. The China's "Law on Compulsory Education" states that all children aged seven to fifteen must enrol and receive compulsory education for nine years. Due to the excess 
population of cities including floaters, the schooling availability becomes uneven. Similar to the health care system, education is also officially under the jurisdiction of the local government. So their funds are limited to educate the children of urban residents (urban hukou). There is no national policy or any regulations on educating the offspring of the floating population. The Central government has provided no funding for migrants. However, a few local bodies had set up unstable, unaccredited make-shift schools to migrants' children. There was a statement of Beijing Municipal Bureau Education regarding this issue in 1996,

Beijing is very short on money for education. Looking after the present million middle and primary school students in the city already strains resources, and there are 300,000 school-age children among the migrant population. Middle and primary schools in the city have already taken in more than 30,000 migrant children. Though the parents of some have paid, the amount of money paid is far from enough to educate these students... formerly these (children) were the responsibility of the receiving area, but nowadays Beijing can't possibly solve the education problems of 300,000 migrant children.

Figure 1 Percentage of long-distance rural migrant workers with social insurance coverage (2010-2014)

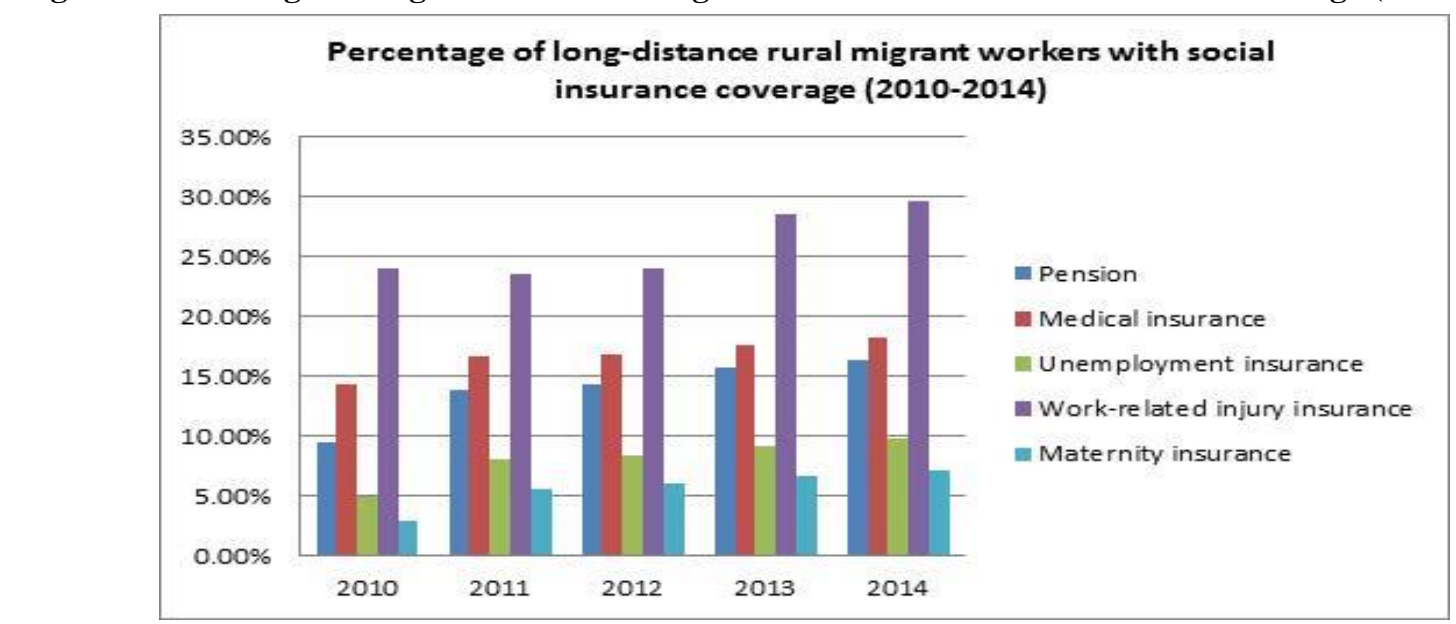

Source: China Labour Bulletin Report, 2015
Normally nowadays the expenditure on education is very high in the cities, without an urban hukou migrants' children are ineligible for free compulsory education. At the same time, they can't afford the city educational expense. Indeed, they send their children back home (village), and they get education and stay with their grandparents. Although, we can find some primary educational institutions like nursery run by migrants in certain migrant enclaves and tutor would be the rural graduate fellow (migrant enclaves in Beijing and Guangdong). Denying education is another necessary right they needed to claim it from the state.

\subsubsection{Rights to Social Security}

With exclusive nature and marginalisation character migrants stay in the periphery of social security schemes too. The sojourners do not have any entitlement to either social security policies of the state or private employers. So they have to take necessary social security policies. The figure 1.1 shows that significant numbers of migrant workers do not get any of the social insurance coverage like pension, medical insurance, unemployment insurance, work-related injury insurance, and maternity insurance. 
Dinamika Sosial Budaya, Vol 21, No. 2, Desember 2019, pp 98-109

p-ISSN: 1410-9859\& e-ISSN: 2580-8524

http://journals.usm.ac.id/index.php/jdsb

Most of the migrant labourers are interested in taking work-related injury insurance which gives an idea that how danger or risky work they involve themselves in. In many cases, they do work in most unsafe conditions without any safety measures. However, less than thirty percentages of migrant workers have gone for such insurance coverage scheme during 2010 to 2014. A very low percentage of workers are only interested in unemployment insurance and medical insurance schemes. Because of low income and high city living expense and not being insured by the employer they hardly have money to go for social insurance coverage to protect their life from many dangerous working environments. The number of the maternity insurance coverage shows the female and married women also actively participate in the urban labour market. Rising work accidental causalities are increasing day by day in different cities of China where they do protest in the street for their compensation.

\section{Is China Abolishing Hukou System?}

Is China planning to abolish its more than six decades hukou system which divided Chinese society into two? This topic has been the point of discussion and debate in China in past few years. The so-called "cities with invisible walls," the hukou excluded and marginalised the sojourning peasants in the cities, which provided all the privileges and rights to urbanites and none to rural migrants. The system always keeps villagers out of many urban jobs, except for those considered less privileged works for city dwellers. These less privileged urban works are also dirty, dangerous and low paid. China's urbanisation policies which are known as "incomplete urbanisation," (Chan and Buckingham, 2008) as practised since reforms, allows peasants entry to the city but always kept them away from permanent residency rights and many other social benefits. The hukou system is a foundation of China's infamous rural-urban "apartheid," creating an artificial division in the urban space. It is a key element of inequality and injustice, perhaps the fundamental part of China's social and spatial stratification. We would say hukou is against the basic rights of peasants who stay in cities, which shows the main reason for their human rights violations. In one side hukou got relaxed and reformed in certain ways so that rural people can freely flow to the cities. But on the other hand they do suffer in the cities due to lack of social welfare benefits provided by state.

Many newspaper reports published in late 2005 understood the most recent round of reform initiatives to suggest that the hukou is set to be abolished, and the rural residents will soon be "granted urban rights." The last round of news on the upcoming abolish of the hukou appeared after Chinese domestic media carried a report by the Ministry of Public Security (MPS) on eliminating the division between agricultural and non-agricultural hukou at a meeting convened by a central committee on public order in late October 2005 (Chan \& Buckingham, 2008:584).

Table 5 Number of nongzhuanfei migrants (1000)

\begin{tabular}{cc}
\hline Year & $\begin{array}{c}\text { Number of nongzhuanfei } \\
\text { migrants }\end{array}$ \\
\hline 1991 & 656 \\
1992 & 1358 \\
1993 & 1265 \\
1994 & 1259 \\
1995 & 1388 \\
1996 & 1202 \\
1997 & 1326 \\
1998 & 929 \\
1999 & 870 \\
2000 & 1003 \\
\hline
\end{tabular}

Source: Guang, 2005:177

The Official English newspaper China Daily reported this news under the title "Rural dwellers to granted urban rights," and hailed the move as a "landmark initiate to abolish the discrimination in the name of hukou in eleven provinces (Chan and Buckingham, 2008). So many international media printed the chorus of the same story. If it so, there are nearly 300 million rural migrants can also get the state provided benefits. 
Dinamika Sosial Budaya, Vol 21, No. 2, Desember 2019, pp 98-109

p-ISSN: 1410-9859\& e-ISSN: 2580-8524

http://journals.usm.ac.id/index.php/jdsb

Chan claims that the abolition of the hukou would come if there is a fundamental shift in rural-urban relations, and it is evident that there has been no such change in the past few years. Fei Ling Wang's findings of the hukou system also says that "this powerful and omnipresent, albeit adapted and adjusted, the system is alive and well" (Wang, 2004:129). After the November report by the MPS, there was no hope or substantive change in peasant migrants' struggle for equality and the rights to the city till now. In contrary to the MPS report on hukou reforms, was an announcement by Shenzhen government body that called for tightening of admission of migrants' children to local public schools. China' abolishing of hukou would be a major revolution on China's path to a modern open and equal social order. China did some experiments with hukou reforms like by introducing nongzhuangfei (农转非) reform which means the process of converting hukou from agricultural to non-agricultural. The hukou migration only officially considered as qianyi (migration) in China, any other mode of internal migration is merely known as liudongrenkou (population movement or floaters). In the late 1990s, any rural to urban migration involving permanent hukou change required both the nongzhuangfei process and a geographical change in residential place. During the 1970s and 80s nongzhuangfei only issues on those recruited as permanent employees by a stateowned enterprise, those enrolled in an institution of higher education, those displaced due to stateinitiated land expropriation, those who joined the army, etc. In a simple word, it was a kind of state-led migration. For each locality, the annual quota of nongzhuangfei was controlled by the central government at 0.15 to 0.2 percent of the non-agricultural population (Chan and Buckingham, 2008:591).

Table 5 shows a statistical representation of nongzhuangfei during 1990 to 2000. The data gives an idea of increasing number of hukou conversion during that decade. Thousands of people converted their hukou status, and those who converted hukou was for the employment in the state-owned enterprises. The height hukou conversion happened in between 1992-1997, which shows the increasing number of hukou migration from rural areas.

The different scholarly articles, studies, and reports say that there was a discussion on abolishing of hukou by the Chinese government, but as of now, they do not want to take it into serious policy implementation. It will be tough to protect millions of migrants under the government's welfare scheme. Any sudden change in hukou policy would might have adverse implications for the entire state machinery. So, China is not going to abolish hukou very soon, but the state tries to come up with some mechanism to reduce the present tension of the rural migrants.

\section{Conclusion}

In China, it is absorbing and important to study the relationship between the hukou and citizenship rights associated with the migrants in the cities. One side, hukou acts as the state machinery to channelize the state provided social benefits to the urban dwellers, and another side, it restricts and controls the population move from the countryside to cities. The hukou is a fundamental tool which determines the rights and privileges and provided the state protection to the urban people and at the same time, it denies the same rights to the transient peasants. The hukou is the major factor which segregates rural migrants from urbanites. Here, it is clear that the hypothesis hukou policies have denied the citizenship rights of the migrant population in Chinese cities is concluded as true and apt in the present circumstances in China. Migrants can only claim full citizenship if there is an abolition of hukou system. Otherwise, they would be treated as second class citizens and continues the injustice and unrest among them, and it will lead to protest and fight for social justice. It is impossible to the state to immediately abolish an institution like hukou because it creates imbalance in the entire system of governance and challenges the state's authority on people. But at the time, the communist state has to come up with some certain remedies to reduce the tension between state and the migrants by making new policies which address the basic issues of the migrants. 
Dinamika Sosial Budaya, Vol 21, No. 2, Desember 2019, pp 98-109

p-ISSN: 1410-9859\& e-ISSN: 2580-8524

http://journals.usm.ac.id/index.php/jdsb

Otherwise, it will lead to affect the stability of the state's political and economic conditions.

\section{Notes:}

*Sumesh Manganelly, currently working as $\mathrm{PhD}$ Research scholar under the Department of Politics at the East China Normal University in Shanghai, China. He has completed his Master of Philosophy (M Phil) program from the Centre for East Asian Studies, School of International Studies, Jawaharlal Nehru University in New Delhi, India in 2016. He has obtained his Master Degree from the Department of Politics and International Studies, Pondicherry University in Puducherry, India in 2014. He completed his Graduation in BSc Statistics from Kannur University in Kerala, India in 2011. His research interest includes the migrant workers, society, political system and international relations of China, Marxism and Ambedkar's writings.

**Hukou is referred as house hold registration system in China which established in 1958 and it determines the one's belonging to the locality. Chinese population has been divided into two under the hukou dual classification which are agricultural and non-agricultural population stay in rural and urban respectively.

\section{Reference}

Becker, J. (2014). Social Ties, Resources, and Migrant Labor Contention in Contemporary China; From Peasants to Protesters. London, United Kingdom: Lexington Books.

Chan, A. (1998). Labor Standards and Human Rights: The Case of Chinese Workers under Market Socialism. Human Rights Quarterly, 20 (4): pp. 886-904.

Chan, A. (2001). Strikes in China's Export Industries in Comparative. The China Journal (The University of Chicago Press), 65: pp. 27-51.

Chan, A. (1998). Labor Standards and Human Rights: The Case of Chinese Workers under Market Socialism. Human Rights Quarterly, 20 (4): pp. 886-904.

Chan, K.W (2001). Recent Migration in China: Patterns, Trends, and Policies. Asian Perspective, 25 (4): pp.127-155

Chan, K.W, Liu, T., \& Yang, Y. (1999). Hukou and Non-hukou Migrations in China: Comparisons and Contrasts. International Journal of Population Geography, pp. 425-448.

Chan, K.W., \& Will, B. (2008). Is China Abolishing the Hukou System?. The China Quarterly (Cambridge University Press), 195: pp. 582-606.

Chan, K. W., \& Zhang, L. (1999). The Hukou System and Rural-Urban Migration in China: Processes and Changes. The China Quarterly (160): pp. 818-855.

China Labour Bulletin Report, Hong Kong, 2015.

Guang, L. (2005). The State Connection in China's Rural-Urban Migration.. International Migration Review (The Center for Migration Studies of New York, Inc.), 39 (2): pp. 354-380.

Kim, J. (2010). Income Inequality in China. The Journal of East Asian Affairs, 24 (2): pp. 29-50.

Lee, C.K (1999). From Organized Dependence to Disorganized Despotism: Changing Labour Regimes in Chinese Factories. The China Quarterly (Cambridge University Press), 157: pp. 44-71.

Li, P., \& Roulleau, B.L. (2013). China Internal and International Migration. New York, USA: Routledge.

Solinger, D.J. (1999). Contesting citizenship in urban China: Peasant Migrants, the State, and the Logic of the Market. Berkely: University of California Press Ltd. 
Dinamika Sosial Budaya, Vol 21, No. 2, Desember 2019, pp 98-109

p-ISSN: 1410-9859\& e-ISSN: 2580-8524

http://journals.usm.ac.id/index.php/jdsb

Shi, L., Hiroshi S., \& Terry S. (ed) (2013). Rising Inequality in China: Challenges to a Harmonious Society. New York: Cambridge University Press.

Wang, F.L. (2004). Reformed Migration Control and New Targeted People: China's hukou System in the 2000s. The China Quarterly (177): pp. 115-132.

Wong, L. (1994), China's Urban Migrants-The Public Policy Challenge. Pacific Affairs, 67 (3): pp. 335-355.

Wu, F., Webster, C., He, S. \& Liu, Y. (eds.) (2014). Urban Poverty in China. Massachusetts, USA: Edward Elgar Publishing, Inc.

Yang, S., \& Li A. (2009). Legal protection against gender discrimination in the workplace in China. Gender and Development, 17 (2): pp. 295-308. 